\title{
New species of Eublaberus Hebard, 1920, new records for the genus and description of the male of $E$. variegatus R. S. Albuquerque, 1972 (Blaberidae, Blaberinae)
}

\author{
Sonia Maria Lopes ${ }^{1,2}$, Edivar Heeren de Oliveira ${ }^{1}$ \& Andrea Khouri ${ }^{1}$ \\ ${ }^{1}$ Universidade Federal do Rio de Janeiro, Museu Nacional, Departamento de Entomologia CEP 20950-040, \\ Rio de Janeiro, RJ, Brazil. \\ ${ }^{2}$ Corresponding author: Sonia Maria Lopes, e-mail: sonialfraga@gmail.com
}

LOPES, S.M., OLIVEIRA, E.H., KHOURI, A. New species of Eublaberus Hebard, 1920, new records for the genus and description of the male of $E$. variegatus R. S. Albuquerque, 1972 (Blaberidae, Blaberinae). Biota Neotropica. 15(2): e20130051. http://dx.doi.org/10.1590/1676-06032015005113

\begin{abstract}
A new species of Eublaberus (E. serranus sp. nov), also a new record for the genus in Southern Brazil, is described based on the male genitalia. The name Eublaberus variegata is corrected to Eublaberus variegatus Rocha e Silva Albuquerque, and the male of the species is described. Illustrations of the genitalia of the two species mentioned are presented and a key to species is also given.

Keywords: Blattaria, morphology, diversity, new taxon, taxonomy.
\end{abstract}

LOPES, S.M., OLIVEIRA, E.H., KHOURI, A. Espécie nova de Eublaberus Hebard, 1920, novo registro para o gênero e descrição do macho de $E$. variegatus R.S. Albuquerque, 1972 (Blaberidae, Blaberinae). Biota Neotropica. 15(2): e20130051. http://dx.doi.org/10.1590/1676-06032015005113

Resumo: Uma nova espécie (E. serranus sp. nov.) com novo registro para o gênero no Sul do Brasil é descrita com base na genitália do macho. O nome de Eublaberus variegata é corrigido para Eublaberus variegatus Rocha e Silva Albuquerque, 1972 e, pela primeira vez, tem a descrição do macho apresentada. A ilustração das genitálias das duas espécies citadas são apresentadas, bem como uma chave para as espécies, a fim de aprimorar o seu conhecimento.

Palavras-chave: Blattaria, morfologia, diversidade, novo táxon, taxonomia.

\section{Introduction}

When Hebard (1920) described Eublaberus based on Blaberus biolleyi Rehn, 1906 he noted that the genus is close to Blaberus, differing from it by having broad interocular space; antennae distinctly tapered; pronotum with lateral margins strongly angulated at the median or mesocephalic portion, or with large mesocephalic convexity. Eublaberus is currently classified in the family Blaberidae, subfamily Blaberinae. Roth (1970), based on characters of the male genitalia, characterized the genus by the presence of preputial spines that occur in a single series of spines, and which can be more or less tapered and sclerotized, and by the configuration of the apex of the median sclerite, hook shaped, which is more distinctly hooked in Eublaberus than in most species of Blaberus. Owing to the hook-shaped median sclerite, Roth (op.cit.) put the group in the tribe Byrsotriini, where Rehn \& Hebard, 1927, Byrsotria Stal, 1874 and Hemiblabera Saussure, 1893 are also included.

More recently, Roth (2003) and Beccaloni (2014) substantiated the classification of Eublaberus in the Blaberinae. Beccaloni includes eight species in the genus, all Neotropical. In Brazil, the genus has been recorded in the North, Northeast, Midwest and Southeast.

Herein we describe a new species (E. serranus) from the state of São Paulo (Brazil), which also represents a new state record for the genus. We also describe the male of E. variegatus Rocha e Silva Albuquerque, 1972 that described by Albuquerque (1972) only by female.

\section{Materials and Methods}

The plates and genital parts were observed by after dissecting the apex of the abdomen of the specimens, using traditional techniques for dissection (Lopes \& Oliveira, 2000).

The terms for the genitalia and taxonomic classification were based on the terms proposed by Roth (2003). The material studied belongs to the Museu Nacional, Universidade Federal do Rio de Janeiro (MNRJ).

\section{Results}

\section{Eublaberus serranus sp.nov.}

General coloration brown (Fig.1a). Pronotum with central disk dark-brown, with two pale and symmetrical areas laterobasally. Head dark-brown, eye black; antennae dark with first 12 antenomeres shiny, remaining fuscous; ocelli, clypeus and gena yellowish, palp dark with golden tomentosity, tegmina with basal stem of veins dark-brown.

Dimensions $(\mathrm{mm})$ : holotype male: total length - 41.2; length of pronotum -9.4 ; width of pronotum -14.0 ; length of 

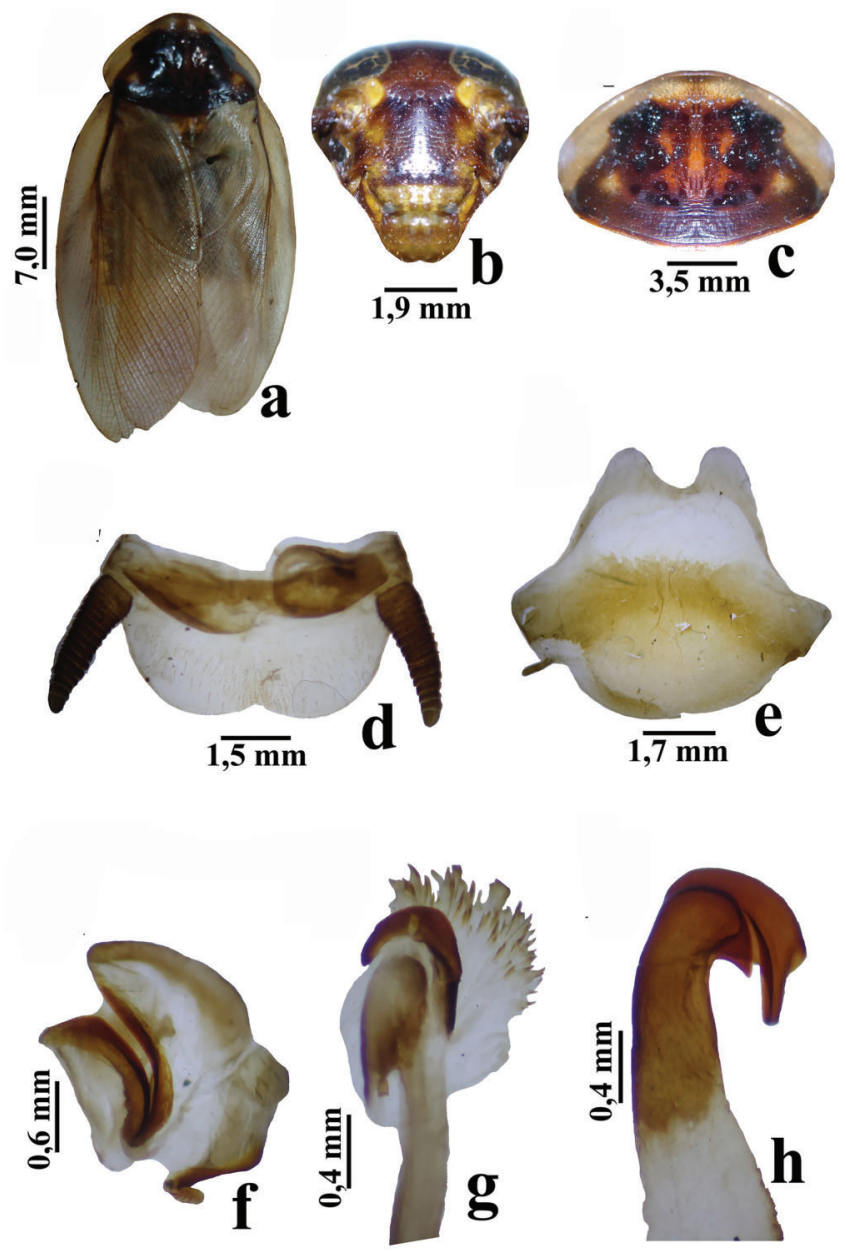

Figure 1. Eublaberus serranus sp. nov. ( 0 ) a. habitus; b. head, ventral; c. pronotum, dorsal; d. supra-anal plate, dorsal; e. subgenital plate, dorsal; f. left phallomere, dorsal; g. apical median phallomere, dorsal; h. right phallomere, dorsal.

tegmen - 34.9 width of tegmen - 12.7; distance between antennal bases: 2.7 .

Head subtriangular (Fig. 1b), antennae tomentose, average in size, not reaching middle of abdomen. Ocelli large and conspicuous; palps tomentose, $3 \mathrm{rd}$ and 5 th articles subequal in length, the latter dilated.

Thorax with pronotum elliptical, transverse, convex (Fig. 1c), lateral flaps with round margins. Legs robust and spiny, fore femur with anteroventral surface bearing a series of small ciliform spines from base to apex, where one is robust; posteroventral surface bearing two robust spines, one on apical third and one more apical; mid femur with anteroventral surface bearing one robust apical spine; posteroventral surface bearing long cilia from base to apex, two robust, one on apical third and one apical; hind femur identical to mid femur, without robust spines posteroventral surface. Tegmen developed reaching beyond apex of cercus; anal field short and deflexed, scapular field long, with oblique venular arrangement; discoidal field ample, venular arrangement ventral tending to longitudinal, anal field ample with twenty or more axillary veins. Wings developed, costal sector with apexes of branches of radial veins not dilated; apical triangle absent and anal field folded as a fan.
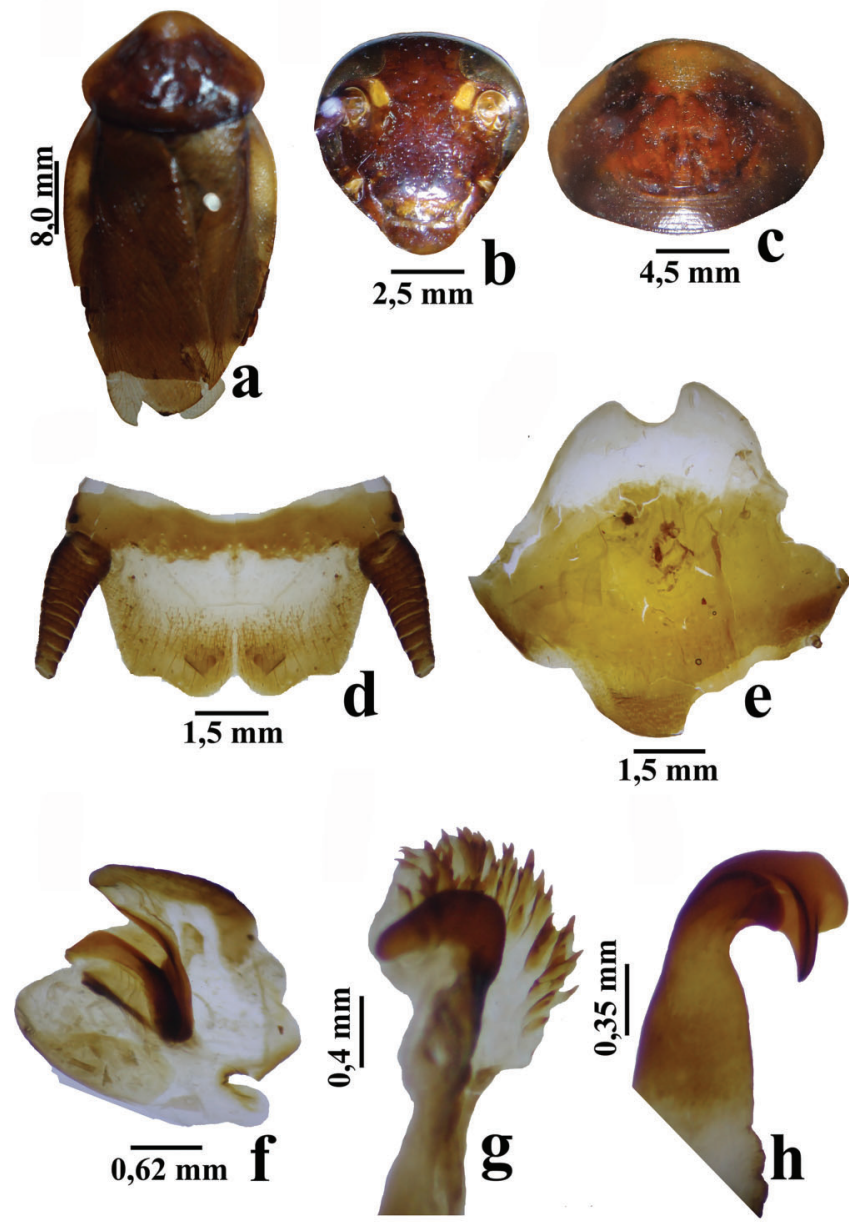

Figure 2. Rocha e Silva-Albuquerque ( $\widehat{o}$ ) a. habitus; b. head, ventral; c. pronotum, dorsal; d. supra-anal plate, dorsal; e. subgenital plate, dorsal; f. left phallomere, dorsal; g. apical median phallomere, dorsal; h. right phallomere, dorsal.

Abdomen with supra-anal and subgenital plates typical of Blaberinae with supra-anal plate with little evident median reentrance; cerci enlarged. Subgenital plate asymmetric, apex rounded, small and thin styles inserted near the side of the plate ends, one of them slightly bent (Figs. 1d e 1e). Genitalia with left phallomere made up by two sclerotized plates (Fig. 1f) with apex narrow, from base to apex hook-shaped, elongate and slender, with pre-apical lateral projection round and prepuce with very small spines (Fig. 1g); right phallomere hook-shaped with apex not slender (Fig. 1h).

Material examined: Holotype male - Brazil, São Paulo, Araras, 07-XI-1984 A.G. Santos col. (MNRJ).

Eublaberus variegatus Rocha e Silva-Albuquerque, 1972

Eublaberus variegata Rocha \& Silva-Albuquerque, 1972: 1-38; Beccaloni, 2014. In site

General coloration shiny brown (Fig. 2a). Pronotum with central disk uniformly dark-brown, tegmen with basal stem of veins dark, head dark-brown; eye dark-brown, ocelli yellowish; palpi brown with golden tomentosity. Legs golden tomentose; pulvilli and apex of claws dark.

Dimensions $(\mathrm{mm})$ : male: total length - 46.26; length of pronotum - 11.72; width of pronotum - 16.79; length of 
tegmen - 39.0; width of tegmen - 13.01; distance between antennal bases -3.6 .

Head subtriangular (Fig. 2b), apex rounded, vertex covered by the pronotum in dorsal view; eye small; interocular space ample, $80 \%$ of the area between bases of antennal sockets; palps tomentose.

Thorax with pronotum elliptical, transverse, convex, lateral flaps ample, and apex slightly protruding (Fig. 2c). Legs robust, fore femur with anteroventral surface bearing series of thin cilia from base to apex and one spine robust; posteroventral surface with sparse cilia, one robust apical, posteroventral surface with a series of cilia and two robust spines, one on apical third and one more apical; hind femur with anteroventral surface bearing sparse cilia and one apical spine; mid and hind femora with one small and robust genicular spine. Pulvilli present, arolia absent, claws symmetrical and simple. Tegmen developed, marginal field long and narrow, scapular field long, with oblique venular arrangement; anal field short and wide. Wings developed, costal sector with apex of branches of radial vein not dilated; apical triangle absent and anal field folded as a fan.

Abdomen with supra-anal plate setose, widened and salient between cerci, with slight median notch (Fig. 2d). Subgenital plates typical of Blaberinae (Fig. 2e). Genitalia with left phallomere made up by two heavily sclerotized plates (Fig. 2f); median sclerite developed with round apex; prepuce with a series of small spines (Fig. 2g); right phallomere elongate, hook-shaped with apex slender (Fig. 2h).

Material examined: 1 male - Brazil, Amazonas, Manaus; 07/VI/1941, no colector data; 1 male - Brazil, Amazonas, Reserva Duque, X/1961, Arlé col.(MNRJ).

\section{Key to the identification of males of Eublaberus Hebard, 1920}

1. Specimens shorter than $40 \mathrm{~mm}$ long . . . . . . . . . . 2 1' Specimens longer than $40 \mathrm{~mm} \ldots \ldots \ldots \ldots$ 2. Pronotum with central disk homogenously dark-brown. . $\ldots \ldots \ldots \ldots \ldots$. argentinus
2' Pronotum dark with latero-apical areas yellowish and two symmetrical, subtriangular, dark-brown marks . . . . . . . ....................... marajoara

3. Pronotum with central disk dark-brown. Apex of median sclerite narrow from base to apex, which is long and slender .................. serranus sp. nov.

3' Pronotum with latero-basal, yellow, circular mark. Apex of median sclerite widened at base and narrowing apically . . . . . . . . . . . . . . E. fernando

3" Pronotum not as above. Apex of median sclerite with apex round $\ldots \ldots \ldots \ldots \ldots \ldots \ldots \ldots \ldots \ldots \ldots \ldots \ldots$

4. Pronotum with central disk with symmetrical light brown marks. Abdomen with sternites light brown with lateral dark marks . . . . . . . . . . . . E. posticus

4'. Pronotum with uniformly dark-brown central disk. Abdomen with uniformly dark brown sclerites ..... E. variegatus

4" Pronotum without dark-brown central disk. Abdomen with sternites yellowish, bearing dark lateral marks .... $\ldots \ldots \ldots \ldots \ldots \ldots \ldots \ldots \ldots \ldots \ldots \ldots$ distanti

\section{References}

BECCALONI, G.W. 2014. Blattodea Species file online. (versão 5.0/5.0). Disponível em: <http://blattodea.speciesfile.org/HomePage.aspx $>$. Acesso em: 18.01.2015.

HEBARD, M. 1920. The Blattidae of Panamá. Memoirs of the American Entomological Society number 4:1-148.

LOPES, S.M. \& OLIVEIRA, E.H. 2000. Espécie nova de Eublaberus Hebard, 1919 do Estado de Goiás, Brasil e notas sobre E. marajoara Rocha e Silva-Albuquerque, 1972 (Blaberidae, Blaberinae). Boletim do Museu Nacional, N. S., Zoologia 433:1-5.

REHN, J.A.G. \& HEBARD, M. 1927. The Orthoptera of the West Indies. Number I. Blattidae. Bulletin American Museum Natural History, N. York, 54:320pp.

ROCHA E SILVA ALBUQUERQUE, I. 1972. Inventário dos Blattaria da Amazônia, com descrição de três espécies novas. Boletim do Museu Paraense Emilio Goeldi (n.s.) Zoologia 76:1-38.

ROTH, L.M. 1970. The male Genitalia of Blattaria. IV. Blaberidae: Blaberinae. Psyche 77(3):308-342.

ROTH, L.M. 2003. Systematics and Phylogeny of Cockroaches (Dictyoptera: Blattaria). Oriental Insects 37:1-183. 